TELEIOS: Jurnal Teologi dan Pendidikan Agama Kristen

Sekolah Tinggi Teologi Transformasi Indonesia

ISSN 2798-0642 (Online), 2798-1797 (Print)

Volume 1, Nomor 2, Desember 2021 (95-105)

DOI: 10.53674/teleios.v1i2.36

stttransformasi-indonesia.ac.id/e-journal/index.php/teleios/index

\title{
Pemuridan dan Kepemimpinan sebuah Perspektif dari Pendidik Kristen
}

\author{
${ }^{1}$ Yakub Hendrawan Perangin Angin, ${ }^{2}$ Yonatan Alex Arifianto, \\ ${ }^{3}$ Tri Astuti Yeniretnowati \\ ${ }^{1,3}$ Sekolah Tinggi Teologi Ekumene, ${ }^{2}$ Sekolah Tinggi Teologi Sangkakala \\ 1'yakubhendrawan@sttekumene.ac.id, ${ }^{2}$ arifianto.alex@ sttsangkakala.ac.id, ${ }^{3}$ triastuti@ sttekumene.ac.id
}

\begin{abstract}
Abstrak:
Pemuridan sangat berkaitan erat dengan kepemimpinan. Pemuridan bagi kepemimpinan sangat bermakna karena sangat terbukti efektif guna mempersiapkan, menghasilkan dan membentuk pemimpin Kristen menuju serupa Yesus. Metode penelitian yang digunakan dalam penelitian ini adalah metode kualitatif dengan pendekatan studi pustaka. Langka awal adalah dengan mempelajari konsep pemuridan dan kepemimpinan Kristen. Langkah berikutnya adalah dengan melakukan analisis tentang dampak bahaya dan dampak positif adanya praktik pemuridan dalam kekristenan bagi kepemimpinan. Langkah terakhir adalah merumuskan makna dan implikasi pemuridan bagi kepemimpinan sebagai perspektif dalam menyusun pola pendidikan pemimpin Kristen. Hasil penelitian ini menyimpulkan bahwa implikasi yang harus dilakukan dan dijalani dalam kehidupan sebagai respon dari penelitian pemuridan dan kepemimpinan ini bagi pola pengajaran dan pendidikan kaderisasi kepemimpinan Kristen, adalah: Pertama, Menjadi pemimpin Kristen yang efektif. Kedua, Pemimpin yang mencetak para pemimpin. Ketiga, Pemimpin yang berani bayar harga. Keempat, Pemimpin yang hidup dalam komunitas pemuridan. Kelima, Mengimplementasikan iman yang dipercayai.
\end{abstract}

Kata Kunci: Pemuridan, Kepemimpinan, Pendidikan Kristen, Kepemimpinan Yesus.

\begin{abstract}
:
Discipleship is closely related to leadership. Discipleship for leadership is very meaningful because it has proven effective in preparing, producing and shaping Christian leaders to be like Jesus. The research method used in this study is a qualitative method with a literature study approach. The first step is to learn the concepts of discipleship and Christian leadership. The next step is to conduct an analysis of the harmful and positive impacts of the practice of discipleship in Christianity for leadership. The final step is to formulate the meaning and implications of discipleship for leadership as a perspective in formulating the pattern of Christian leader education. The results of this study conclude that the implications that must be carried out and lived in life as a response to this discipleship and leadership research for the pattern of teaching and cadre education for Christian leadership are: First, Become an effective Christian leader. Second, Leaders who print leaders. Third, leaders who dare to pay the price. Fourth, Leaders who live in a community of discipleship. Fifth, implement the faith that is believed.
\end{abstract}

Keywords: Discipleship, Leadership, Christian Education, Jesus Leadership. 


\section{Pendahuluan}

Permasalahan mendasar dalam kekristenan saat ini adalah menerima bentuk kehidupan kekristenan tanpa pemuridan, yang ciri kekristenannya menghasilkan banyak kegiatan, konferensi dan program, tetapi tanpa transformasi kekal (perubahan konsistensi jangka panjang menuju keserupaan dengan Yesus). ${ }^{1}$ George Barna yang adalah presiden dari Barna Research Group menyatakan, tentang kekristenan dewasa ini, bahwa: "Bagi para gembala sidang dan staf gereja, pemuridan adalah kata yang melelahkan. Bagi kebanyakakan orang awam, kata pemuridan tidak ada maknanya." 2 Menarik apa yang disarankan oleh George Barna bagi gereja dengan hasil fenomena tentang kekristenan dewasa ini yang digambarkan dengan pernyataan di atas, yaitu: Pertama, Gereja diajak untuk terpaku pada kegagalan dalam menghasilkan peniru-peniru Kristus yang tidak kenal lelah. Kedua, Gereja diajak untuk semakin termotivasi oleh pengaruhnya yang semakin berkurang di dalam dunia ini. Dan Ketiga, Gereja diajak agar berkomitmen guna melaksanakan apa pun yang dibutuhkan dalam menghidupkan gereja yang mempermuliakan Allah, menolong mengubahkan hidup, serta mengambil bagian yang strategis dalam transformasi kehidupan umat manusia. Ketiga poin ini dilakukan gereja dengan mengingat dan menaati apa yang Tuhan Yesus perintah terakhir sebelum kenaikan ke sorga: "Kepada-Ku telah diberikan segala kuasa di sorga dan di bumi. Karena itu pergilah, jadikanlah semua bangsa murid-Ku dan baptislah mereka dalam nama Bapa dan Anak dan Roh Kudus, dan ajarlah mereka melakukan segala sesuatu yang telah Kuperintahkan kepadamu. Dan ketahuilah, Aku menyertai kamu senantiasa sampai kepada akhir zaman" (Mat. 28:18-20). ${ }^{3}$

Padahal ketika berbicara mengenai pelayanan yang menghasilkan pemimpin yang setia dalam mengikut Yesus, tidak ada yang lebih organik daripada pemuridan. Faktanya pertumbuhan organic mengambil bentuk sel-sel yang dinamis dan bermultiplikasi, hal ini berbeda sekali dengan pendekatan linier yang dibatasi dengan sekolah-sekolah teologi, gelar, iklan dan bangunan. Sama seperti sel yang hidup menduplikasikan diri sendiri secara eksponensial, tubuh Kristus berkembang ke segala arah. Untuk itulah pelayanan pemuridan lebih membutuhkan relasi berkualitas tinggi daripada pelayanan lainnya. Mengacu pada model Perjanjian Baru, di mana setiap anggota saling melayani Allah, maka menghasilkan murid Kristus yang sejati adalah harapan terbaik dalam memaksimalkan pelayanan anggota kepada anggota di dalam gereja masa kini. ${ }^{4}$ Gereja saat ini memerlukan orang Kristen yang berkualitas imannya yaitu para pengikut Yesus Kristus yang dewasa penuh, untuk itu diperlukan perubahan radikal melalui metode yang pernah Yesus gunakan untuk mengubah dunia. Metode yang Yesus ajarkan dan perintahkan kepada gereja dalam menghasilkan pemimpin yang mampu memimpin orang lain kepada Yesus Kristus itu adalah pemuridan yang relasional. ${ }^{5}$

Masalah utama lainnya yang dihadapi gereja saat ini berkaitan dengan pemuridan dan kepemimpinan adalah ketersediaan dan kecakapan para pemimpin dan pendeta atau gembala

\footnotetext{
${ }^{1}$ Bill Hull, Jesus Christ, Disciplemaker, 1st ed. (Surabaya: Literatur Perkantas Jawa Timur, 2015).

${ }^{2}$ George Barna, Menumbuhkan Murid-Murid Sejati, 1st ed. (Jakarta: Metanoia, 2010).

${ }^{3}$ Ibid.

${ }^{4}$ Dennis McCallum and Jessica Lowery, Organic Discipleship, 1st ed. (Surabaya: Literatur Perkantas Jawa Timur, 2015).

${ }^{5}$ Jim Putman, Bobby Harrington, and Robert E. Coleman, Discipleshift, 1st ed. (Yogyakarta: Yayasan Gloria, 2016), 25-26.
} 
dalam mengawal dan memastikan pertumbuhan rohani dan relasi umat komunitas gereja. Pemimpin gereja yang siap memelihara para pembimbing (yang memuridkan) orang percaya dalam Kristus, dan menyediakan tempat yang aman serta penuh kasih bagi anggota jemaat gereja. Tanggung jawab pemimpin gereja adalah menginspirasi dan mendukung orang-orang yang sudah terpanggil untuk memuridkan (membimbing) dalam komunitas kecil (kelompok kecil). ${ }^{6}$

Bill Hull mengutip apa yang dikatakan oleh Dietrich Bonhoeffer, bahwa: "Kekristenan tanpa pemuridan sama saja dengan kekristenan tanpa Kristus." Tanpa pemuridan, tidak ada kekristenan, karena pemuridanlah yang menghidupkan iman Kristen. Pemuridan berarti ketaatan kepada Kristus, dan karena Kristus adalah objek dari ketaatan tersebut, maka bentuk dari ketaatan ini adalah pemuridan. Kekristenan tanpa pemuridan jauh lebih menguasai pola pikir kebanyakan gereja masa kini. Selain mengisap apa yang menjadi kekekuatan gereja, kekristenan tanpa pemuridan juga telah membuat gereja meleburkan diri dengan budaya di sekelilingnya. Yang paling sangat tragis dan menyedihkan adalah ketika definisi moralitas antara gereja dan budaya tidak lagi menunjukkan perbedaan, maka dapat dipastikan gereja kehilangan kuasa dan otoritasnya. ${ }^{7}$

\section{Metode Penelitian}

Metode penelitian yang digunakan dalam penelitian ini adalah metode kualitatif dengan pendekatan studi pustaka. Langka awal adalah dengan mempelajari konsep pemuridan dan kepemimpinan Kristen. Langkah berikutnya adalah dengan melakukan analisis tentang dampak bahaya dan dampak positif adanya praktik pemuridan dalam kekristenan bagi kepemimpinan. Langkah terakhir adalah merumuskan makna dan implikasi pemuridan bagi kepemimpinan sebagai perspektif dalam menyusun pola pendidikan pemimpin Kristen. Sumber utama dari pembahasan konsep pemuridan kepemimpinan Kristen berasal dari beberapa sumber yang relevan, hasil penelitian dari jurnal dan buku teks yang sesuai dengan topik pemuridan dan kepemimpinan. Semua sumber selanjutnya dianalisis dengan cara mencermati hubungan dan kecocokan dengan tema penulisan. Hasil kajian tentang pemuridan dan kepemimpinan sebagai sebuah perspektif pendidikan pemimpin Kristen ke depan. Hasil analisis selanjutnya diuraikan secara deskriptif dan sistematis. ${ }^{8}$

\section{Hasil dan Pembahasan}

Hubungan pemuridan dan kepemimpinan dalam perspektif pendidikan Kristen sangatlah penting dan mendasar, bahkan pendidikan Kristen dalam unit terkecil yaitu keluarga sangat berpengaruh utama dalam menghasilkan orang Kristen yang berkualitas sesuai dengan yang Allah inginkan. Hal ini ditegaskan oleh Matt Chandler dan Adam Griffin yang menyatakan bahwa: "Pemuridan keluarga adalah kepemimpinan rohani yang penting dengan memimpin

${ }^{6}$ Bill Donahue, Membimbing Kelompok Kecil Untuk Mengubah Hidup, 1st ed. (Yogyakarta: Gloria Graffa, 2010), 30 .

${ }^{7}$ Bill Hull, Panduan Lengkap Pemuridan, 1st ed. (Yogyakarta: Yayasan Gloria, 2014), 13-14.

${ }^{8}$ Sonny Eli Zaluchu, "Struktur Artikel Untuk Jurnal Ilmiah Dan Teknik Penulisannya," in Strategi Menulis Jurnal Untuk Ilmu Teologi, ed. Sonny Eli Zaluchu, 1st ed. (Semarang: Golden Gate Publishing Semarang, 2020), $1-21$. 
keluarga melakukan apa pun dan kapan pun serta di mana pun guna menolong anggota keluarga menjadi sahabat dan pengikut Yesus Kristus." Bahkan dikatakan selanjutnya, bahwa: "Orang Kristen harus memuridkan inilah peran hakiki setiap orang Kristen dan setiap orang tua Kristen." Dari pernyataan ini sangatlah jelas bagaimana kaitan pemuridan dan kepemimpinan dalam pendidikan Kristen harus dimulai dari keluarga, hal yang sama tentunya berlaku dalam komunitas orang percaya yaitu gereja. Gereja yang tidak melakukan pemuridan sudah pasti akan mengalami permasalahan dalam kepemimpinan gereja.

Bill Hull yang adalah salah satu tokoh Kristen dewasa ini yang banyak menulis pemuridan dan kepemimpinan serta gereja, menyatakan pentingnya pemuridan dan kepemimpinan sebagai sebuah perspektif pendidikan Kristen yang sangat diperlukan oleh gereja dewasa ini guna menjawab permasahalan kekristenan saat ini. Pendapat yang dinyatakannya, yaitu dengan mengadopsi lima praktik pemuridan yang berlangsung pada abad pertama, sebagaimana dimodifikasi oleh Yesus Kristus, yaitu rahasia bagi transformasi pribadi yang akan mengarah pada transformasi gereja yang akan menghasilkan transformasi budaya, yaitu: Pertama, Seorang murid menundukkan diri pada seorang pemimpin yang mengajarkannya bagaimana mengikut Yesus. Kedua, Seorang murid mempelajari firman Yesus. Ketiga, Seorang murid mempelajari bagaimana Yesus melayani. Keempat, Seorang murid mencontoh hidup dan karakter Yesus. Kelima, Seorang murid mencari dan mengajar murid-murid lain untuk mengikut Yesus. ${ }^{10}$

\section{Kepemimpinan Yesus}

Kehidupan Kristus yang mengosongkan diri itu menjadi fondasi dalam menjadikan murid. ${ }^{11}$ Banyak hal yang dilakukan Yesus merupakan teladan bagi orang percaya. Tujuan pemuridan adalah keserupaan dengan Kristus, dan memperhatikan kehidupan Yesus agar semakin dewasa di dalam iman. Sebelum Yesus fokus melakukan sesuatu, Yesus fokus dalam relasi dengan Allah dan para murid-Nya. Dalam melakukan misi-Nya, Yesus tidak hanya fokus pada tugas-tugas pelayanan atau bahkan menghabiskan sebagian besar waktu-Nya untuk berkhotbah, menyembuhkan, mengajar. Yesus sering membawa para murid-Nya menyingkir dari orang banyak untuk beristirahat. Dengan melihat hidup-Nya, orang percaya bisa mengerti bahwa buah pelayanan bukan saja soal menyingsingkan lengan baju dan bekerja lebih keras. Yesus memakai metode, dan metode itulah yang seharusnya juga orang percaya gunakan. ${ }^{12}$

Seorang pemimpin mengikuti teladan Yesus jika pemimpin tersebut tidak terlibat secara pribadi dalam pekerjaan membuat murid di semua aspek. Jika seorang pemimpin tidak membangun dan memelihara relasi-relasi penting yang membuatnya dapat memperlengkapi orang lain untuk mengikut Yesus, maka pemimpin tersebut tidak sedang melakukan yang dicontohkan Yesus. ${ }^{13}$ Yesus menggunakan model pemberdayaan kepemimpinan dan pelatihan para pelayan. Ketika para pendeta dan pemimpin pelayanan saat ini cenderng puas memiliki

\footnotetext{
${ }^{9}$ Matt Chandler and Adam Griffin, Family Discipleship (Pemuridan Keluarga), 1st ed. (Yogyakarta: Katalis, 2021), 32.

${ }^{10}$ Hull, Jesus Christ, Disciplemaker.

${ }^{11}$ Neil T. Anderson, Menjadi Gereja Pembuat Murid, 1st ed. (Yogyakarta: Katalis, 2016), 26.

12 Putman, Harrington, and Coleman, Discipleshift.

13 Ibid.
} 
jemaat yang bergantung pada pengajaran dan perhatiannya, Yesus mengnginkan pengikut yang berinisiatif, berbuah dan berkomitmen penuh. Yesus berpikir bahwa pelipatgandaan pelayanan dengan memilih beberapa orang merupakan ukuran keberhasilan-Nya. ${ }^{14}$

Yesus juga mendidik para murid-Nya untuk menjadi pelayan. Yesus mengajarkan bahwa para murid-murid-Nya tidak boleh meneladani atau mencontoh apa yang diperagakan oleh pemimpin-pemimpin orang farisi karena sering kali berlaku sebagai bos atau majikan terhadap orang yang pimpinannya. Para murid diingatkan Yesus tidak boleh mengingini posisi menjadi yang terhebat atau terutama atau terbesar di dalam komunitasnya. Malahan Yesus mengajarkan kalau orang yang memerintah justru seharusnya menjadi orang yang melayani, karena "Aku ada di tengah-tengah kamu sebagai pelayan" (Luk. 22:27). Dalam perjamuan malam terakhir Yesus bersama keduabelas murid-murid-Nya di ruang atas, Yesus mengambil handuk dan seember air lalu membasuh kaki para murid-Nya, sungguh mengagetkan suatu tindakan pelayanan yang rendah hati yang diwariskan Yesus bagi para murid dan para pengikut-Nya. "Jadi jikalau Aku membasuh kakimu, Aku yang adalah Tuhan dan Gurumu, maka kamupun wajib saling membasuh kakimu" (Yoh. 13:14). ${ }^{15}$

\section{Kiprah Paulus Dalam Pemuridan dan Kepemimpinan}

Tugas utama dari Paulus ketika memuridkan murid-muridnya, seperti Timotius, Priskila dan Akwila adalah bagaimana mengajar para penatuan gereja akan keselamatan, penyerahan diri kepada ketuhanan Kristus. Kehidupan para pemimpin gereja secara komunal harus menjadi area utama dimana para pemimpin dibentuk ke dalam kehidupan yang baru sebagai murid. Tugas Paulus adalah membantu para orang Kristen mengenali kehidupan seperti apa yang seharusnya dijalani orang-orang yang mengikut Yesus. Di tengah berbagai macam persoalan yang harus diselesaikan, Paulus perlu memastikan bahwa orang percaya memahami idestitas utamanya dalam Kristus, dan mengetahui bagaimana akan membentuk semua tindakan dalam kehidupan sehari-hari. ${ }^{16}$

Paulus adalah seorang pekabar Injil, misionaris perintis dan penanam gereja, yang tujuan utamanya adalah untuk memenangkan para petobat. Namun iti hanyalah satu sisi dari gambaran tentang Paulus. Paulus menulis bahwa kerinduannya yang besar adalah beranjak melampaui pekabaran Injil kepada pemuridan dan menjadikan setiap orang dewasa di dalam Kristus. Inilah tujuan yang sungguh-sungguh menguras tenaganya, demikianlah pula pemimpin Kristen semestinya. "Itulah yang kuusahakan dan kupergumulkan dengan segala tenaga sesuai dengan kuasa-Nya, yang bekerja dengan kuat di dalam aku" (Kol. 1:29). Memang benar bahwa Paulus sanggup berjuang hanya dengan kekuatan dari Kristus. Tetapi, meskipun memiliki kekuatan ilahi yang demikian, Paulus tetap bekerja keras dan berjuang, tidak terkecuali dalam doa dan belajar. Tidak ada tujuan yang lebih tinggi dari pelayanan. Slogan ini sungguh indah bagi setiap orang yang terpanggil dalam kepemimpinan pemuridan. Adanya kerinduan untuk

\footnotetext{
${ }^{14}$ Greg Ogden, Transforming Discipleship, 1st ed. (Surabaya: Literatur Perkantas Jawa Timur, 2014).

15 Tony Horsfall, Mentoring Conversations (Percakapan-Percakapan Untuk Bimbingan Rohani), 1 st ed. (Yogyakarta: Katalis, 2021), 74.

${ }^{16}$ Neil Hudson, Imagine Church, 1st ed. (Surabaya: Literatur Perkantas Jawa Timur, 2017), 52.
} 
mempersembahkan setiap orang yang dipercayakan kepada orang percaya untuk menjadi dewasa di dalam Kristus. ${ }^{17}$

\section{Dampak Bahaya Kepemimpinan Kristen Tanpa Pemuridan}

Tim Staf Perkantas menginventarisasi bahaya-bahaya Kekristenan apabila pemuridan tidak berjalan sebagaimana mestinya, yaitu: Pertama, Akan lahir orang Kristen formalis, fenomena dan simbolis. Kekristenan seperti ini hanya memiliki legalitas sebagai anggota gereja atau aktivis persekutuan yang hanya menunjukkan cara hidup yang sepertinya Kristiani, namun sesungguhnya jauh dari Tuhan. Kedua, Persekutuan dan gereja hanya mentransfer metode kegiatan atau kebiasaan baru tanpa perubahan esensi. Maksudnya adalah anggota gereja atau persekutuan terbiasa dengan berbagai metode dan aneka ragam kegiatan rohani, rajin, dan aktif mengikuti kegiataan gereja, namun tidak menunjukkan perubahan yang signifikan, khususnya dalam etika dan cara hidup. Ketiga, Muncul "Farisi" dan "ahli Taurat" baru, dimana kebenaran firman yang diketahui bahkan ahli dan mengausai teologi serta hafal ayat, namun tidak diperagakan maka akan jadi topeng dan tembok yang digunakan seorang pemimpin untuk menutupi kejahatannya. Keempat, Keanggotaan gereja dan persekutuan bagaikan keanggotaan sebuah klub atau arisan. Kelima, Kekeristenan tidak berdampak. Orang Kristen tahu betapa pentingnya menjadi berkat bagi sesame, namun kualitas dan kapasitas yang rendah tidak memungkinkan hal tersebut terjadi. Kegelapan dan pembusukan dunia bukannya semakin berkurang, malah sebaliknya orang-orang Kristen juga banyak menceburkan diri ke dalam kejahatan dunia. Keenam, Misi integral (proklamasi dan demonstrasi) menjadi utopis, dimana misi akan terkendala tanpa kualitas murid yang baik. ${ }^{18}$ Uraian yang dijelaskan pada paragraph di atas ini mulai dari poin satu sampai keenam, ini menunjukkan bahwa kepemimpinan tanpa adanya pemuridan, suatu saat akan mengakibatkan kekosongan atau ketidakstabilan dalam menghasilkan regenerasi pemimpin, tentu saja hal ini akan sangat berdampak pada kelangsungan pelayanan dan mutu dari pendidikan Kristen di masa depan.

\section{Dampak Pemuridan Bagi Kepemimpinan}

Pemuridan inti dari perintah Yesus kepada para pengikut-Nya. Pemuridan bukan saja menunjukkan interaksi-interaksi Allah dengan para murid-ya, tetapi juga merupakan cara utama para pemimpin Kristen, dalam berinvestasi pada orang lain. ${ }^{19}$ Mempertegas apa yang menjadi tujuan dan ciri dari pemimpin gereja, di mana melalui pemuridan dapat menolong sebanyak mungkin orang untuk menemukan identitas dan talenta yang dimilikinya dalam Kristus. ${ }^{20}$ Para pemimpin (kelompok kecil) mulai sungguh-sungguh menggembalakan kelompok-kelompok rumah tangganya yang meliputi berbagai generasi. Pemuridan kelompok kecil menjadi DNA dasar pelayanan yang mempengaruhi segala hal para pemimpin lakukan dalam pertumbuhan gereja. Para pemimpin dan anggota transparan mengenai pergumulan dan kegagalan yang dialami. Para anggota pemuridan saling memerhatikan dan memiliki relasi-

17 John Stott, The Radical Disciple, 1st ed. (Surabaya: Literatur Perkantas Jawa Timur, 2010).

${ }^{18}$ Tim Staf Perkantas, Pemuridan Dinamis Membangun Bangsa, 1st ed. (Jakarta: Literatur Perkantas, 2013), 9-11.

${ }^{19}$ Bobby Harrington and Alex Absalom, Discipleship That Fits, 1st ed. (Yogyakarta: Katalis, 2018), 33.

${ }^{20}$ Harrington and Absalom, Discipleship That Fits. 
relasi pribadi yang mendalam. Kehidupan komunitas yang saling menolong dalam persoalanpersoalan hidup yang nyata, saling memberi dan menerima pertanggungjawaban (akuntabilitas) serta saling mendukung dan menguatkan. ${ }^{21}$

Setiap murid Yesus dipanggil untuk menerapkan dan membagikan kebenaran. Dengan kata lain, semua orang percaya yang sudah dimuridkan dipanggil untuk menghasilkan buahbuah kebenaran. Melakukan dan membagikan firman adalah konsekuensi logis sebagai murid yang meneladani Sang Guru Agung. Status orang yang sudah percaya kepada Kristus bukan hanya sebagai anak-anak Allah, tetapi murid-murid Yesus yang senantiasa belajar menaati Bapa, sama seperti Kristus. Memahami, melakukan, dan membagikan firman merupakan jantung kehidupan seorang murid dan jawaban umat terhadap panggilan Tuhan untuk menaati Allah. ${ }^{22}$ Perubahan perspektif pemimpin akibat pemuridan, berdampak terjadinya perubahan hidup seorang anak Allah menuju keserupaan dengan Yesus, inilah yang disebut sebagai proses menjadi murid Yesus. Juga menjadi murid yang menggenapi amanat Yesus, untuk pergi menjadikan murid-murid lagi di antara segala suku bangsa, yang akan terus berlipatganda bagi kemuliaan Allah. ${ }^{23}$

\section{Implikasi Pemuridan dan Kepemimpinan di Masa Kini}

Menjadi Pemimpin Kristen Yang Efektif

Menjadi pemimpin gereja yang efektif meliputi: Pertama, Menemukan tujuan yang tepat, yaitu menjadikan murid, bukan hanya menghasilkan para petobat. Kedua, Mendefinisikan murid dengan tepat, seorang yang mengikut Yesus, diubahkan oleh Yesus, dan berkomitmen melakukan misi Yesus. Ketiga, Menggunakan metodologi yang tepat, lingkungan-lingkungan yang relasional, intensional, dan alkitabiah. Keempat, Menghasilkan buah yang dimaksudkan, murid-murid yang sehat secara rohani dan relasi, dan yang terus-menerus menghasilkan muridmurid lagi. ${ }^{24}$ Bagi Yesus relasi adalah segalanya. Yesus hidup dan mengajar, menjadi teladan dan menjelaskan makna mengasihi Allah dan sesama Relasi Yesus dengan Bapa-Nya menunjukkan natur relasi kasih sejati seorang anak dengan Allah Bapa. Pelayanan Yesus kepada orang lain menggambarkan arti sesungguhnya dari mengasihi sesama. Pengikut Yesus menjadi murid ketika memahami teladan dan pengajaran-Nya. Yesus memanggil murid-muridNya untuk hidup menurut dua prioritas, yaitu: mengasihi Allah dan mengasihi sesame. Jika para pemimpin Kristen mengikuti pengajaran dan teladan dari Yesus, nilai-nilai ini seharusnya memiliki dampak pembentukan gaya pada diri seorang pemimpin Kristen sebagai murid Yesus. $^{25}$

\section{Pemimpin Yang Mencetak Para Pemimpin}

${ }^{21}$ Avery T. Willis Jr. and Mark Sonwden, Truth That Sticks (Kebenaran Yang Melekat), 1st ed. (Yogyakarta: Katalis, 2017), 99.

22 Ajeng Chrissaningrum and Tim Kambium Yayasan Gloria, Bertumbuh Dalam Kristus Pemuridan Melalui Waktu Teduh, ed. Petrus Budi Setyawan, Okdriati S. Handoyo, and Tri Puji Lestari, 1st ed. (Yogyakarta: Yayasan Gloria, 2012).

${ }^{23}$ Okdriati S. Handoyo, "Pelipatgandaan Rohani 'Berakar Dalam Kristus,"” in Berakar Dalam Kristus Pemuridan Melalui Waktu Teduh, ed. Okdriati S. Handoyo and Johan Setiawan, 2nd ed. (Yogyakarta: Yayasan Gloria, 2012), 164.

${ }^{24}$ Putman, Harrington, and Coleman, Discipleshift.

${ }^{25}$ Richard Lamb, Menjadi Murid Yesus Di Kehidupan Nyata, 2nd ed. (Jakarta: Literatur Perkantas, 2011). 
Peran utama seorang pemimpin atau pendeta di gereja adalah mencetak dan mengembangkan para pemimpin. Setiap orang percaya adalah murid yang harus bertumbuh menjadi pembuat murid yang efektif, tetapi tidak semua orang memiliki karunia sebagai pemimpin. Seorang pemimpin harus mengetahui adakah bibit pemimpin-pemimpin bertalenta untuk menolongnya bertumbuh. ${ }^{26}$ Orang percaya perlu diinjili tentang penginjilan yang memuridkan supaya setiap orang percaya membuat pilihan untuk hidup dalam pemuridan. Tetapi, pada saat yang sama, orang percaya juga bergumul untuk mengikut Yesus. ${ }^{27}$ Para pemimpin pemuridan hanya dapat menjadi pembuat murid jika para pemimpin ini juga sedang dimuridkan. ${ }^{28}$

Pemimpin Kristen dipanggil untuk dapat menghasilkan berbuah di dalam Kristus dengan melipatgandakan kehidupan sebagai murid Kristus pada diri setiap pengikutnya, menjadi pemimpin yang menghasilkan pemimpin, menjadi murid yang memuridkan. Ada tiga fakta yang mendasari panggilan, yaitu: Pertama, Amanat Agung yang diwariskan Sang Guru Agung Yesus dalam Matius 20:18-20. Kedua, banyak orang termasuk yang mengikuti seorang pemimpin yang perlu dimuridkan sebagaimana dinyatakan dalam Matius 9:37, "Tuaian memang banyak, tetapi pekerja sedikit". Untuk itu panggilan untuk menjadikan pekerja yang memuridkan tidak dapat ditunda. Ketiga, setiap murid dapat memuridkan, setiap pemimpin dan menghasilkan pemimpin jika bergantung kepada Tuhan, mengasihi orang lain, dan mau rela mengiring Yesus untuk menjadi serupa dengan-Nya. ${ }^{29}$

Bill Donahue menyatakan bahwa, yang paling strategis dalam proses perubahan hidup di gereja adalah pemimpin kelompok kecil atau pemuridan. Prioritas pembimbing kelompok kecil (pemimpin pemuridan) tidak dapat bertumbuh dengan sendirinya atau dibiarkan saja. Para pemimpin perlu dipertemukan secara berkala dengan pemimpin lain untuk saling memberikan dukungan dan pertanggungjawaban (persekutuan pemimpin). Tujuan utama setiap pemimpin adalah perubahan hidup, yakni menolong anggota kelompok pemuridannya bertumbuh dalam karakter melalui belajar, saling mengasihi, serta berbagi diri dan berkat. Pemimpin juga harus membantu para murid yang dibimbingnya untuk bertambah jumlahnya, yang pada akhirnya dapat melahirkan kelompok kecil atau kelompok pemuridan baru. ${ }^{30}$

\section{Pemimpin Yang Berani Bayar Harga}

Harga yang harus di bayar oleh seorang pemimpin dalam mengikut Yesus Kristus adalah kesediaan untuk menyangkal diri, memikul salib dan mengikut Yesus setiap waktu. Para pemimpin adalah pelayanan iman dalam kasih. Matanya harus tertuju pada Tuhan, dan hatinya harus terarah kepada orang-orang yang sedang dibantunya. Seperti yang disampaikan Rasul Paulus kepada jemaat Galatia, "Layanilah seorang akan yang lain oleh kasih" (Gal. 5:13). Para pemimpin memandang dirinya sebagai pelayan yang rela, demi orang-orang yang sedang dibantunya, ditolongnya. Orang yang berpusat pada diri sendiri, yang serakah dan mencari

\footnotetext{
${ }^{26}$ Putman, Harrington, and Coleman, Discipleshift.

${ }^{27}$ Bill Hull, Choose The Life, 2nd ed. (Surabaya: Literatur Perkantas Jawa Timur, 2015).

${ }^{28}$ Harrington and Absalom, Discipleship That Fits.

${ }^{29}$ Petrus Budi Setyawan, "Menularkan Berbuah Dalam Kristus," in Berbuah Dalam Kristus, ed. Johan Setiawan and Okdriati S. Handoyo, 1st ed. (Yogyakarta: Yayasan Gloria, 2015), 164.

${ }^{30}$ Donahue, Membimbing Kelompok Kecil Untuk Mengubah Hidup.
} 
keuntungan pribadi tidak dapat menjadi pemimpin yang memperlengkapi orang lain. Kerendahan hati, rela berkorban, dan jiwa yang melayani yang Yesus tunjukkan merupakan unsur utama pelayanan pemimpin yang efektif. ${ }^{31}$

\section{Pemimpin Yang Hidup Dalam Komunitas Pemuridan}

Alkitab menyatakan dengan jelas, bahwa kehidupan Kristen tidak pernah dimaksudkan untuk dijalani sendirian. Orang-orang yang sudah menerima Kristus kini terhubung melalui kehidupan bersama dalam persekutuan orang percaya untuk hidup dalam komunitas. Identitas orang Kristen bermuara pada pembentukan komunitas yang sama-sama mengasihi Allah, karena dengan kesamaan itu merupan bagian dari tubuh Kristus. Orang percaya saling membutuhkan satu sama lain untuk saling menolong menjadi seperti Kristus dan meneladani hidup Yesus secara konsisten. ${ }^{32}$ Setidaknya ada dua alasan penting mengapa komunitas pemuridan merupakan sarana yang layak diandalkan untuk proses menghasilkan pemimpin yang handal, yaitu: Pertama, Teladan Kristus sendiri. Kedua, Bagaimana metode tersebut terbukti efektif untuk memenuhi kebutuhan orang-orang yang baru mengenal Kristus. ${ }^{33}$

Amanat Agung mengacu pada pengkaderisasian murid. Menjadikan murid berasal dari rencana penebusan Allah. Inilah isi hati Allah bagi umat-Nya, bagi dunia. Jika orang Kristen percaya bahwa Yesus sama dengan yang difirmankan-Nya dan orang percaya melakukan yang Yesus perintahkan, maka orang percaya adalah murid. Jadi proses menjadikan murid sama dengan menceritakan kepada orang lain tentang Yesus dan memanggil orang-orang untuk mengikut Yesus. ${ }^{34}$

\section{Mengimplementasikan Iman Yang Dipercayai}

Murid dibentuk oleh Yesus. Yesus adalah pembuat dan penyempurna iman setiap pemimpin Kristen yang mengaku sebagai murid Yesus. Yesuslah yang membentuk dan memuridkan. Ketika Yesus pertama kali memanggil para murid, Yesus berkata, "Mari, ikutlah Aku dan kamu akan Kujadikan penjala manusia" (Mrk. 1:17). Makna kata "akan" dalam ayat di atas adalah suatu proses panjang yang Yesus adakan dalam hidup para pemimpin yang adalah murid-Nya dalam perjalan waktu. Itu bukan suatu pemberian yang langsung terjadi, tapi hasil dari relasi intim dan panjang dalam perjalanan waktu. Orang percaya tidak dapat bertumbuh tanpa Dia. Para pemimpin Kristen dapat menempatkan diri pada posisi yang bisa mendatangkan pengalaman hidup yang kaya dan berkemenangan yang telah Allah rancangkan bagi setiap anak-anak-Nya. Ini adalah inti dari apa yang dinyatakan sebagai "pemuridan". ${ }^{35}$

Seorang pemimpin harus bisa diteladani dan berani menyatakan komitmennya, sebagaimana teladan Paulus yang mengajarkan dan mengimplementasikan firman Allah dalam

${ }^{31}$ Leroy Eims and Randy Eims, Laboring In The Harvest, 1st ed. (Yogyakarta: Yayasan Gloria - Katalis, 2015), 113.

${ }^{32}$ Randy \& Robert Noland Frazee, Berpikir, Bertindak, Menjadi Seperti Yesus, 1st ed. (Yogyakarta: Yayasan Gloria, 2016).

${ }^{33}$ Sutrisna, Visi Pemuridan, 1st ed. (Bandung: Mitra Pustaka \& Literatur Perkantas Jawa Barat, 2006), 24.

${ }^{34}$ Francis Chan and Mark Beuving, Multiply, 1st ed. (Yogyakarta: Katalis, 2017).

${ }^{35}$ Robby Gallaty, Rediscovering Discipleship, 1st ed. (Surabaya: Literatur Perkantas Jawa Timur, 2018), 74. 
kehidupan sebagai murid Yesus secara nyata. ${ }^{36}$ Karena itulah, Paulus menulis kepada orang percaya di Korintus, "Jadilah pengikutku, sama seperti aku juga menjadi pengikut Kristus," (1 Kor. 11:1), dan "Sebab itu aku menasihatkan kamu: turutilah teladanku" (1 Kor. 4:16). Kepada jemaat di Filipi, "Saudara-saudara, ikutlah teladanku dan perhatikanlah mereka, yang hidup sama seperti kami yang menjadi teladanmu" (Fil. 3:19), dan pada bagian lainnya Paulus sampaikan "Dan apa yang telah kamu pelajari dan apa yang telah kamu terima, dan apa yang telah kamu dengar dan apa yang telah kamu lihat padaku, lakukanlah itu" (Fil. 4:9). ${ }^{37}$

Akhirnya para pemimpin yang terlibat aktif membuat murid tidak hanya membuktikan ketaatannya dalam melakukan metode Yesus ajarkan, tetapi juga taat menjadi murid yang sekaligus pemimpin dalam melengkapi orang Kristen lainnya (Ef. 4:11-13 dan 2 Tim. 2:2). Tanggung jawab para pemimpin gereja adalah memperlengkapi, melatih, dan mendampingi para anggota dalam melakukan pelayanan menjadi murid yang menjadikan murid selanjutnya. Menanam gereja dari murid-murid yang membuat murid bukan saja dapat dilakukan, tetapi juga merupakan perintah Yesus kepada gereja-Nya. Ketika para pemimpin Kristen menjadikan pelipatgandaan murid sebagai prioritas utamanya, para pemimpin Kristen memimpin dan memungkinkan gereja-gereja saat ini maupun yang akan datang untuk menemukan tempatnya di dalam misi Yesus dan rencana agung-Nya dalam menebus umat-Nya. ${ }^{38}$

\section{Kesimpulan}

Proses pemuridan sangat terbukti efektif guna mempersiapkan, menghasilkan dan membentuk pemimpin Kristen yang memiliki dasar-dasar kehidupan rohani yang baik dan sehat yang membawa kepada kerinduan hidup untuk mencontoh apa yang Yesus Kristus wariskan. Implikasi dari penulisan jurnal ini terkait topik pemuridan dan kepemimpinan sebuah perspektif dari pendidikan Kristen ada beberapa poin, yaitu: Pertama, Menjadi pemimpin Kristen yang efektif. Kedua, Pemimpin yang mencetak para pemimpin. Ketiga, Pemimpin yang berani bayar harga. Keempat, Pemimpin yang hidup dalam komunitas pemuridan. Kelima, Mengimplementasikan iman yang dipercayai.

\section{Referensi}

Anderson, Neil T. Menjadi Gereja Pembuat Murid. 1st ed. Yogyakarta: Katalis, 2016.

Barna, George. Menumbuhkan Murid - Murid Sejati. 1st ed. Jakarta: Metanoia, 2010.

Chan, Francis, and Mark Beuving. Multiply. 1st ed. Yogyakarta: Katalis, 2017.

Chandler, Matt, and Adam Griffin. Family Discipleship (Pemuridan Keluarga). 1st ed. Yogyakarta: Katalis, 2021.

Chrissaningrum, Ajeng, and Tim Kambium Yayasan Gloria. Bertumbuh Dalam Kristus Pemuridan Melalui Waktu Teduh. Edited by Petrus Budi Setyawan, Okdriati S. Handoyo, and Tri Puji Lestari. 1st ed. Yogyakarta: Yayasan Gloria, 2012.

Donahue, Bill. Membimbing Kelompok Kecil Untuk Mengubah Hidup. 1st ed.

\footnotetext{
${ }^{36}$ Harrington and Absalom, Discipleship That Fits.

37 Ibid.

${ }^{38}$ Bobby Harrington and Josh Patrick, Buku Panduan Pembuat Murid, 1st ed. (Yogyakarta: Katalis, 2017), $215-216$.
} 
Yogyakarta: Gloria Graffa, 2010.

Eims, Leroy, and Randy Eims. Laboring In The Harvest. 1st ed. Yogyakarta: Yayasan Gloria - Katalis, 2015.

Frazee, Randy \& Robert Noland. Berpikir, Bertindak, Menjadi Seperti Yesus. 1st ed. Yogyakarta: Yayasan Gloria, 2016.

Gallaty, Robby. Rediscovering Discipleship. 1st ed. Surabaya: Literatur Perkantas Jawa Timur, 2018.

Handoyo, Okdriati S. "Pelipatgandaan Rohani 'Berakar Dalam Kristus." In Berakar Dalam Kristus Pemuridan Melalui Waktu Teduh, edited by Okdriati S. Handoyo and Johan Setiawan. 2nd ed. Yogyakarta: Yayasan Gloria, 2012.

Harrington, Bobby, and Alex Absalom. Discipleship That Fits. 1st ed. Yogyakarta: Katalis, 2018.

Harrington, Bobby, and Josh Patrick. Buku Panduan Pembuat Murid. 1st ed. Yogyakarta: Katalis, 2017.

Horsfall, Tony. Mentoring Conversations (Percakapan-Percakapan Untuk Bimbingan Rohani). 1st ed. Yogyakarta: Katalis, 2021.

Hudson, Neil. Imagine Church. 1st ed. Surabaya: Literatur Perkantas Jawa Timur, 2017. Hull, Bill. Choose The Life. 2nd ed. Surabaya: Literatur Perkantas Jawa Timur, 2015. 2015.

\section{- Panduan Lengkap Pemuridan. 1st ed. Yogyakarta: Yayasan Gloria, 2014.}

Jr., Avery T. Willis, and Mark Sonwden. Truth That Sticks (Kebenaran Yang Melekat). 1st ed. Yogyakarta: Katalis, 2017.

Lamb, Richard. Menjadi Murid Yesus Di Kehidupan Nyata. 2nd ed. Jakarta: Literatur Perkantas, 2011.

McCallum, Dennis, and Jessica Lowery. Organic Discipleship. 1st ed. Surabaya: Literatur Perkantas Jawa Timur, 2015.

Ogden, Greg. Transforming Discipleship. 1st ed. Surabaya: Literatur Perkantas Jawa Timur, 2014.

Perkantas, Tim Staf. Pemuridan Dinamis Membangun Bangsa. 1st ed. Jakarta: Literatur Perkantas, 2013.

Putman, Jim, Bobby Harrington, and Robert E. Coleman. Discipleshift. 1st ed. Yogyakarta: Yayasan Gloria, 2016.

Setyawan, Petrus Budi. "Menularkan Berbuah Dalam Kristus." In Berbuah Dalam Kristus, edited by Johan Setiawan and Okdriati S. Handoyo. 1st ed. Yogyakarta: Yayasan Gloria, 2015.

Stott, John. The Radical Disciple. 1st ed. Surabaya: Literatur Perkantas Jawa Timur, 2010.

Sutrisna. Visi Pemuridan. 1st ed. Bandung: Mitra Pustaka \& Literatur Perkantas Jawa Barat, 2006.

Zaluchu, Sonny Eli. "Struktur Artikel Untuk Jurnal Ilmiah Dan Teknik Penulisannya.” In Strategi Menulis Jurnal Untuk Ilmu Teologi, edited by Sonny Eli Zaluchu, 1-21. 1st ed. Semarang: Golden Gate Publishing Semarang, 2020. 